\title{
The Effect of Brand Image and Price on Customer Satisfaction in Purchasing Es Kopi Susu Keluarga at FamilyMart Jakarta
}

\author{
Muhammad Sedky ${ }^{\mathrm{a}}$, Setyo Riyanto ${ }^{\mathrm{b}}$ \\ ${ }^{a}$ Master of Management Student, Universitas Mercu Buana, Jakarta, Indonesia \\ ${ }^{\mathrm{b}}$ Associate Professor, Universitas Mercu Buana, Jakarta, Indonesia
}

\begin{abstract}
Coffee has become a lifestyle requirement for people in Jakarta. Many new businesses take advantage of this opportunity; one of them is FamilyMart. FamilyMart is a Japanese retail company that also sells food and beverages, one of the popular products is the iced Kopi Kopi Keluarga. The purpose of this research is to analyze and explain the effect of corporate image, store image, product image and price on customer satisfaction in purchasing Es Kopi Susu Keluarga. This research method uses descriptive methods and quantitative approaches using questionnaires as research instruments. The number of samples used was 59 respondents. Conclusion of the results of the analysis of this study found that the variables significantly influence the variable of customer satisfaction.
\end{abstract}

Keywords:- Brand Image, Customer Satisfaction.

\section{INTRODUCTION}

Coffee consumption has become a necessity for employees who mostly work in Jakarta as a dish to accompany work time or to relax while resting. The competition for coffee businesses in Jakarta is very large, starting from those who prioritize the quality of taste, the interior of the place, and the price. Many coffee shops have sprung up in Jakarta to reach the workforce segment, so they open their shops in the office area. The need for fast coffee serving due to limited employee time and not being able to wait long becomes an opportunity for Family Mart to be able to compete in the coffee industry in Jakarta.

Family Mart is a Japanese retail company that opens more than 150 branches in several office buildings in Jakarta, in addition to focusing on selling daily goods, Family Mart also sells fast food, so that only needs to be warmed up in the microwave and also drinks such as coffee and green tea with models personal service business, One of the famous and popular menus is Es Kopi Susu Keluarga, a blend of coffee, milk, and palm sugar. The thing that makes it famous and much in demand is the price that is fairly cheap, plus the quality of taste that is not inferior to its competitors in the market.

Brand Image is a collection of associations about a brand that is stored in the minds of consumers. The high brand image of a brand can be useful to more easily get customer loyalty. When a brand has gotten a positive image in the eyes of consumers, then indirectly, consumers will come to the brand and will make repeated transactions. Consumers will also definitely refer the brand to other people. In addition to this, the price must also be a major concern for Family Mart to be able to compete, although it is well known, Family Mart does not set high prices for Es Kopi Susu Keluarga products which are expected to cause customer satisfaction. In this study, the influence of brand image and price on customer satisfaction in purchasing Es Kopi Susu Keluarga at the Family Mart will be analyzed.

\section{LITERATURE REVIEW}

\section{$>$ Brand Image}

According to Kotler (2009), mentioning brand image is people's perception of the company or its products. The image is influenced by many factors that are outside the company's control. A useful image will affect three things: first, strengthening the product's character and the proposed value. Second, conveying the role differently, so it is not confused with the character of competitors. Third, it provides emotional strength that is more than a mental image. The image must be conveyed through every available means of communication and brand contact.

According to Simamora (2006), the image is a relatively consistent perception in the long term (enduring perception). So it is not easy to form an image, so if it is created, it is difficult to change it. Brand Image is a representation of the overall perception of the brand and is formed from information and experience of the brand. The image of a brand is related to attitudes in the form of beliefs and preferences towards a brand. Consumers who have a positive image of a brand will be more likely to purchase (Setiadi, 2003). Components of a brand image according to Simamora (2011) consists of three parts, namely:

- The image of the maker (corporate image) is a collection of associations perceived by consumers of the company that makes an item or service.

- User image, a group of associations that consumers perceive users using goods or services.

- Product image, a collection of associations that consumers perceive of an item or service.

\section{Price}

Price is a measure of the size of one's satisfaction with the product purchased.1 Someone will dare to pay for a product at a high price if he assesses the satisfaction he expects for the product to be bought is top. Conversely, if a 
person evaluates his satisfaction with a product is low, he will not be willing to pay or buy the product at a high price. Price becomes a measure for consumers where it has difficulty in assessing the quality of complex products offered to meet the needs and desires if the goods the consumer wants are excellent quality goods. The price is high; otherwise, if what the customer wants is of ordinary quality- mediocre or not too good, then the price is not too high.

\section{Customer Satisfaction}

According to Kotler (2007), customer satisfaction is a feeling of pleasure or disappointment someone who appears after comparing the performance (results) of products thought to the expected performance. Consumer satisfaction is a situation that is shown by consumers when they realize that their needs and desires are as expected and are met properly.

\section{Methodology of Research}

This type of research conducted in this study uses analytical research (explanatory research). By emphasizing the quantitative approach, this research is to explain the partial and simultaneous influence between Corporate Image $\left(\mathrm{X}_{1}\right)$, User Image $\left(\mathrm{X}_{2}\right)$, and Product Image $\left(\mathrm{X}_{3}\right)$ and Price $\left(\mathrm{X}_{4}\right)$, variables on Customer Satisfaction on puscharing Es Kopi Susu Keluarga FamilyMart (Y). Questionnaires were distributed to 59 FamilyMart Customer in Jakarta. Analysis of the data used are:

\section{Descriptive Analysis}

The analysis is used to analyze data by describing or describing the data collected as it is without intending to make general conclusions or generalizations.

\section{Multiple Linear Regression Analysis}

As a predictive analysis, the multiple linear regression is used to explain the relationship between one continuous dependent variable and two or more independent variables

\section{T-Test Analysis (Partial Test)}

The t-test serves to test the significance of each of the independent variables $\left(\mathrm{X}_{1}, \mathrm{X}_{2}, \mathrm{X}_{3}\right.$, and $\left.\mathrm{X}_{4}\right)$ partially to determine the most dominant influence between the Corporate Image, Store Image, Product Image and Price variables on the Customer Satisfaction on purchasing Es Kopi Susu Keluarga

\section{F Test Analysis (Simultaneous Test)}

$\mathrm{F}$ test is used to test significant or not simultaneously or influential together between independent variables to the dependent variable.

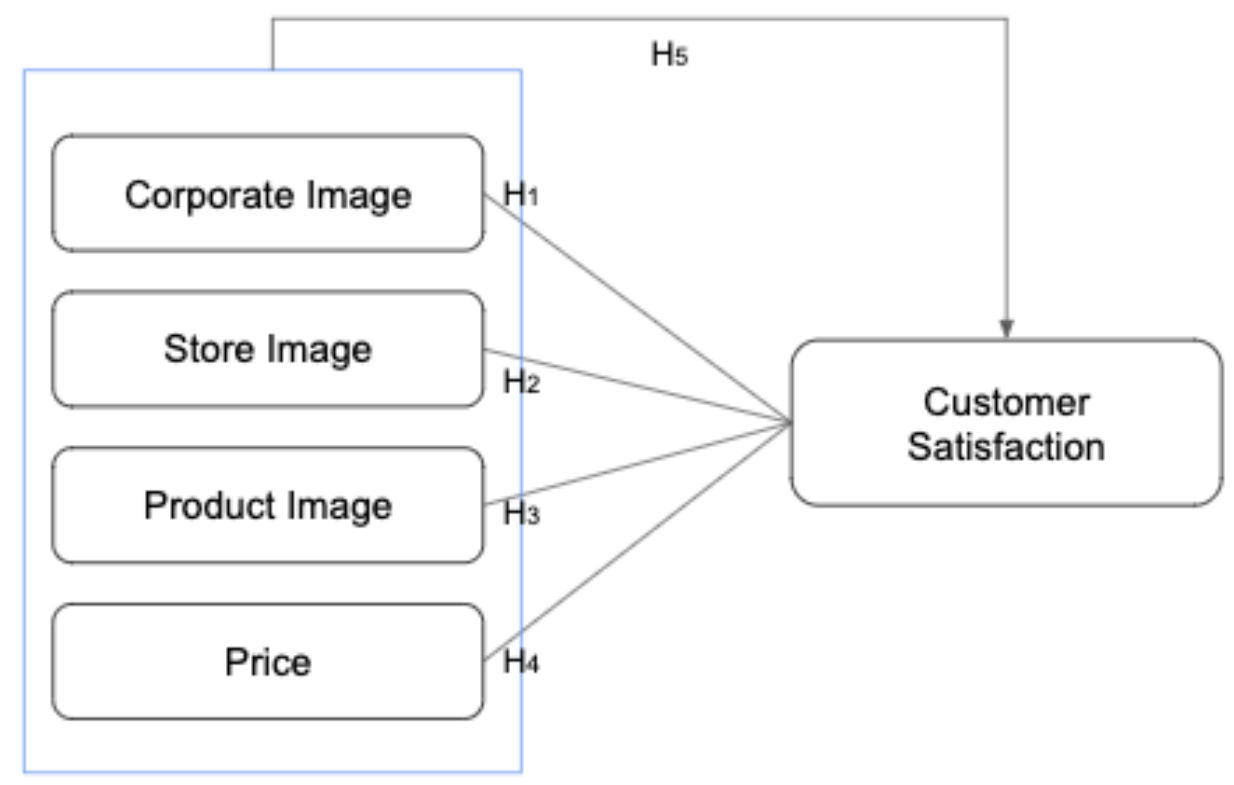

Fig 1:- Framework Model

\section{Hypothesis}

H1: Corporate Image affects the Training Effectiveness

H2: User Image affects Training Effectiveness

H3: Product Image affects Training Effectiveness

H4: Price affects Training Effectiveness

H5: Corporate image, store image, product image and price together have a significant effect on the customer satisfaction in purchasing Es Kopi Susu Keluarga 


\section{RESULT AND DISCUSSION}

After distributing the questionnaire and processing the data obtained using SPSS 23.0 for Windows, the results of data processing and discussion in this study were obtained from distributing questionnaires to 59 FamilyMart Customer in Jakarta as the primary data source. From this, it is also a known description of the characteristics of respondents on research as follows:

\begin{tabular}{|c|c|c|c|}
\hline Description & Type & Amount & Percentage \\
\hline \multirow[t]{2}{*}{ Gender } & Man & 25 & $42,3 \%$ \\
\hline & Woman & 34 & $57,7 \%$ \\
\hline \multirow[t]{3}{*}{ Age } & $<25$ Years & 15 & $25,4 \%$ \\
\hline & $26-30$ Years & 25 & $42,3 \%$ \\
\hline & $>31$ Years & 19 & $32,2 \%$ \\
\hline \multirow[t]{3}{*}{ Buying Intensity } & 1 time per month & 19 & $32,2 \%$ \\
\hline & 2-3 times per month & 16 & $27,1 \%$ \\
\hline & $>4$ times per month & 24 & $40,6 \%$ \\
\hline \multirow[t]{4}{*}{ Monthly Expense } & <Rp. 1.000 .000 & 1 & $0,01 \%$ \\
\hline & Rp. 1.000.001-Rp. 2.000 .000 & 8 & $0,13 \%$ \\
\hline & Rp. 2.000.001 - Rp. 3.000 .000 & 10 & $16,9 \%$ \\
\hline & >Rp. 3.000 .001 & 42 & $71,1 \%$ \\
\hline
\end{tabular}

Table 1:- Description of Research Objective

\section{Analysis of Research Results}

To test whether the measuring instrument that is used meets the requirements of a suitable measuring instrument, to produce data following what is measured, before analyzing the data based on the results of the data collected, the data is tested through the validity and reliability of the data.

\begin{tabular}{|c|c|c|c|}
\hline Questions & R $_{\text {count }}$ & Rable $_{\text {talion }}$ & Information \\
\hline Question 1 $\left(\mathrm{X}_{1}\right)$ & 0,777 & 0,278 & Valid \\
\hline Question 2 $\left(\mathrm{X}_{1}\right)$ & 0,893 & 0,278 & Valid \\
\hline Question 1 $\left(\mathrm{X}_{2}\right)$ & 0,890 & 0,278 & Valid \\
\hline Question 2 $\left(\mathrm{X}_{2}\right)$ & 0,908 & 0,278 & Valid \\
\hline Question 1 $\left(\mathrm{X}_{3}\right)$ & 0,854 & 0,278 & Valid \\
\hline Question 2 $\left(\mathrm{X}_{3}\right)$ & 0,928 & 0,278 & Valid \\
\hline Question 1 $\left(\mathrm{X}_{4}\right)$ & 0,729 & 0,278 & Valid \\
\hline Question 2 $\left(\mathrm{X}_{4}\right)$ & 0,794 & 0,278 & Valid \\
\hline Question 3 $\left(\mathrm{X}_{4}\right)$ & 0,785 & 0,278 & Valid \\
\hline
\end{tabular}

Table 2:- Recapitulation of Validity Test on Corporate Image $\left(\mathrm{X}_{1}\right)$, Store Image $\left(\mathrm{X}_{2}\right)$, Product Image $\left(\mathrm{X}_{3}\right)$ and Price $\left(\mathrm{X}_{4}\right)$

Validity testing in this study was done by correlating the scores of each item statement addressed to respondents with a total score for all items. The results of the variable $\mathrm{X} 1$ test indicate that all statements for the user corporate image $\left(\mathrm{X}_{1}\right)$, store image $\left(\mathrm{X}_{2}\right)$, product image $\left(\mathrm{X}_{3}\right)$ and price $\left(\mathrm{X}_{4}\right)$ are validly used as a measurement of research and can be used for further analysis.

\begin{tabular}{|c|c|c|c|}
\hline Questions & Rcount & rTable & Information \\
\hline Question 1 & 0,842 & 0,278 & Valid \\
\hline Question 2 & 0,862 & 0,278 & Valid \\
\hline Question 3 & 0,835 & 0,278 & Valid \\
\hline Question 4 & 0,919 & 0,278 & Valid \\
\hline Question 5 & 0,905 & 0,278 & Valid \\
\hline
\end{tabular}

Table 3:- Recapitulation of Validity variable of Training Effectiveness (Y)

Source : Data Processing Result 2020

Y Variable Test results show that all statements for the variable customer satisfaction on purchasing Es Kopi Susu tetangga are valid as a measurement of research and can be used for further analysis. 


\section{Reliability Test}

The questionnaire is said to be reliable if the reliability coefficient is positive and is greater than 0.60 . The results of the reliability test based on the alpha Cronbach formula obtained the following results:

\begin{tabular}{|c|c|c|c|}
\hline Variable & $\begin{array}{c}\text { Reliability } \\
\text { Coefficient }\end{array}$ & $\begin{array}{c}\text { Critical } \\
\text { Point }\end{array}$ & 0,6 \\
\hline Corporate Image $\left(\mathrm{X}_{1}\right)$ & 0,659 & 0,6 & Reliable \\
\hline Store Image $\left(\mathrm{X}_{2}\right)$ & 0,762 & 0,6 & Reliable \\
\hline Product Image $\left(\mathrm{X}_{3}\right)$ & 0,723 & 0,6 & Reliable \\
\hline Price $\left(\mathrm{X}_{4}\right)$ & 0,644 & 0,6 & Reliable \\
\hline Customer Satisfaction $(\mathrm{Y})$ & 0,736 & 0 \\
\hline
\end{tabular}

Table 4:- Reliability Test Results of Research Questionnaire

Source : Data Processing Result 2020

Based on table 4 above, the reliability value of the statement item on the questionnaire for each variable being studied is more significant than 0.60 , the reliability value of the corporate image $\left(\mathrm{X}_{1}\right)$ is 0.659 , store image $\left(\mathrm{X}_{2}\right)$ is 0.762 , product image $\left(\mathrm{X}_{3}\right)$ is 0.723 and price $\left(\mathrm{X}_{4}\right)$ is 0.644 . The reliability value of the variable customer satisfaction (Y) amounted to 0.736 . These results indicate that the statement items on the questionnaire are reliable to measure the variables.

\section{Hypothesis Testing Analysis}

Following the formulation of the problem, research objectives, hypotheses, and types of data collected, the analytical method used in this study is multiple linear regression analysis. Multiple linear regression analysis is used to determine the magnitude of the relationship and influence, which includes: the influence of the user interface, material presentation, and quiz presentation on the effectiveness of customer service training.

\section{Analysis of Multiple Linear Regression Equations}

The multiple regression model that will be formed is as follows:

$\mathrm{Y}=\mathrm{b}_{0}+\mathrm{b}_{1} \mathrm{X}_{1}+\mathrm{b}_{2} \mathrm{X}_{2}+\mathrm{b}_{3} \mathrm{X}_{3}+\mathrm{b}_{4} \mathrm{X}_{4}$

Where:

$\mathrm{Y} \quad=$ Customer Satisfaction on purchasing Es Kopi Susu Keluarga

$\mathrm{X}_{1} \quad=$ Corporate Image

$\mathrm{X}_{2} \quad=$ Store Image

$\mathrm{X}_{3} \quad=$ Product Image

$\mathrm{X}_{4} \quad=$ Price

$\mathrm{b}_{0} \quad=$ intercept

$\mathrm{b}_{123} \quad=$ Regression Coefficient

By using SPSS, the regression coefficient results are obtained as follows:

\begin{tabular}{|c|c|c|c|c|c|c|}
\hline \multicolumn{7}{|c|}{ Coefficients $^{\mathrm{a}}$} \\
\hline & \multirow[b]{2}{*}{ Model } & \multicolumn{2}{|c|}{ Unstandardized Coefficients } & \multirow{2}{*}{$\begin{array}{c}\text { Standardized } \\
\text { Coefficients } \\
\text { Beta }\end{array}$} & \multirow[b]{2}{*}{$\mathrm{T}$} & \multirow[b]{2}{*}{ Sig. } \\
\hline & & $\mathrm{B}$ & Std. Error & & & \\
\hline \multirow[t]{5}{*}{1} & (Constant) & ,470 & 1,390 & & ,338 & ,737 \\
\hline & Corporate Image &, 014 & ,138 & ,317 &, 102 & ,920 \\
\hline & Store Image & 149 &, 151 & 140 & ,984 & ,330 \\
\hline & Product Image & ,333 &, 152 & ,247 & 2,168 & ,034 \\
\hline & Price & .634 &, 133 &, 569 & 4,779 & ,000 \\
\hline \multicolumn{7}{|c|}{ a. Dependent Variable: Customer Satisfaction } \\
\hline
\end{tabular}

Table 5:- Regression Coefficient Result

From Table 5 above, it is known the constant value and the regression coefficient so that it can be formed multiple linear regression equations as follows:

$\mathrm{Y}=0,470+0,014 \mathrm{X}_{1}+0,149 \mathrm{X}_{2}+0,333 \mathrm{X}_{3}+0,634 \mathrm{X}_{4}$ 
Partial Hypothesis Testing ( $t$-Test)

By using the SPSS program, the following outputs are obtained:

\begin{tabular}{|c|c|c|c|c|c|c|}
\hline \multicolumn{7}{|c|}{ Coefficients $^{\mathbf{a}}$} \\
\hline \multirow{2}{*}{\multicolumn{2}{|c|}{ Model }} & \multicolumn{2}{|c|}{ Unstandardized Coefficients } & \multirow{2}{*}{$\begin{array}{c}\begin{array}{c}\text { Standardized } \\
\text { Coefficients }\end{array} \\
\text { Beta }\end{array}$} & \multirow[b]{2}{*}{$\mathrm{T}$} & \multirow[b]{2}{*}{ Sig. } \\
\hline & & $\mathrm{B}$ & Std. Error & & & \\
\hline \multirow[t]{5}{*}{1} & (Constant) & 0,470 & 1,390 & & 0,338 & 0,737 \\
\hline & Corporate Image & 0,140 & 0,138 & 0,012 & 0,102 & 0,920 \\
\hline & Store Image & 0,149 & 0,151 & 0,130 & 0,984 & 0,330 \\
\hline & Product Image & 0,333 & 0,152 & 0,247 & 2,188 & 0,034 \\
\hline & Price & 0,634 & 0,133 & 0,569 & 4,779 & 0,000 \\
\hline
\end{tabular}

Table 6:- Pengujian Hipotesis Parsial

- Hypothesis testing variable X1 (corporate image) is accepted, meaning that the corporate image has a significant effect on the customer satisfaction in purchasing Es Kopi Susu Keluarga. Corporate image is how the public, in this case, the buyer, supplier, consumer, or society as a whole perceives the company. The public obtained the perception from various information provided by the company and translated by the public. Based on data processing, consumer perception of the FamilyMart company, a trusted multinational company that has many branches in the world. In Indonesia alone, there are already 180 branches available. That image makes consumers fasting with FamilyMart's service in presenting coffee as one of the superior products sold.

- Hypothesis testing variable X2 (store image) is accepted, meaning that the presentation of material has a significant effect on the effectiveness of customer service training. FamilyMart launches three innovations in technology that all aim to facilitate consumers and the application of cashless in purchasing coffee. The three innovations are called digital services and are claimed to be the first in Asia and even Japan as the owner of the FamilyMart brand, not yet implementing the system. Ordering kiosk, FamilyMart mobile app, and self-service payment, Ordering kiosk is a food and beverage ordering service through a screen found in FamilyMart outlets. The sophisticated shop is the image that FamilyMart wants to put forward. Another thing that is prepared to meet customer satisfaction is a cashier who specializes in purchasing food and drinks so that the manufacturing process can be faster.

- Hypothesis testing variable $\mathbf{X}_{3}$ (product image) is accepted, meaning that the product image has a significant effect on customer satisfaction in purchasing Es Kopi Susu Keluarga. The product image, which is perceived as superiority ES Kopi Susu Keluarga is a taste that can be compared to coffee shops from luxury shops around Jakarta. The right material composition creates a good perception for consumers.

- Hypothesis testing variable $\mathbf{X}_{4}$ (Price) is accepted, meaning that price has a significant effect on customer satisfaction in purchasing Es Kopi Susu Keluarga. Price is the main advantage of Coffee Family Ice Coffee. Only with Rp. 13,000, consumers can already enjoy the product. Low prices do not reduce the quality of flavors offered.

\section{Simultaneous Hypothesis Testing (F-Test)} obtained:

By using the SPSS program, the following output is

\begin{tabular}{|c|c|c|c|c|c|c|}
\hline \multicolumn{7}{|c|}{ ANOVA $^{a}$} \\
\hline \multicolumn{2}{|c|}{ Model } & Sum of Squares & Df & Mean Square & $\mathrm{F}$ & Sig. \\
\hline \multirow[t]{3}{*}{1} & Regression & 90.924 & 4 & 22.731 & 20.843 &, $000^{\mathrm{b}}$ \\
\hline & Residual & 49.076 & 45 & 1.091 & & \\
\hline & Total & 140.000 & 49 & & & \\
\hline \multicolumn{7}{|c|}{ a. Dependent Variable: Effectiveness of Customer Service Training } \\
\hline
\end{tabular}

Table 7:- Simultaneous Hypothesis Testing 
Based on Table 7 above, $\mathrm{H}_{5}$ is accepted, meaning that variable of the corporate image, store image, product image and price together influences customer satisfaction in purchasing Es Kopi Susu Keluarga.

\section{Analysis of the Coefficient of Determination}

After knowing the value of $\mathrm{R}$ (Correlation) of 0.806 , the coefficient of determination can be calculated using the following formula:

\begin{tabular}{|c|c|c|c|c|}
\hline \multicolumn{5}{|c|}{ Model Summary } \\
\hline Model & $\mathrm{R}$ & R Square & $\begin{array}{c}\text { Adjusted R } \\
\text { Square }\end{array}$ & $\begin{array}{c}\text { Std. Error of } \\
\text { the Estimate }\end{array}$ \\
\hline 1 &, $806^{\mathrm{a}}$ &, 649 &, 618 & 1,044 \\
\hline \multicolumn{5}{|c|}{. Predictors: (Constant), Price, Corporate Image, Store } \\
Image, Product Image \\
\hline
\end{tabular}

Tabel 8:- Result of the Coefficient of Determination

$$
\begin{gathered}
\mathrm{KD}=\mathrm{R}^{2} \times 100 \% \\
=(0,806)^{2} \times 100 \% \\
=64,9 \%
\end{gathered}
$$

The KD value of $64,9 \%$ is obtained, which indicates the meaning that $X_{1}$ (Corporate Image), $X_{2}$ (Store Image), $\mathrm{X}_{3}$ (Product Image), $\mathrm{X}_{4}$ (Price) gives a simultaneous effect of $64,9 \%$ on the customer satisfaction in purchasing Es Kopi Susu Keluarga (Y) while the remaining 35,1\% is influenced by other factors not examined in this study.

\section{CONCLUSION}

There are a positive influence of the corporate image, store image, product image and price on the customer satisfaction in purchasing Es Kopi Susu Keluarga. Brand Image berpengaruh besar terhadap kepuasan pelanggan FamilyMart.

\section{REFERENCES}

[1]. Bilson, Simamora. 2011. Memenangkan Pasar Dengan Pemasaran Efektif Dan Profitabel. Jakarta: PT Gramedia Pustaka Utama

[2]. J. Setiadi, Nugroho, SE., MM., 2003, "Perilaku Konsumen Konsep dan Implikasi untuk Strategi dan Penelitian Pemasaran". Jakarta: Kencana.

[3]. Kotler dan Keller, 2007. Manajemen Pemasaran, Edisi 12, Jilid 1, PT.Indeks, Jakarta.

[4]. Kotler, P., Keller, K.L., Brady, M., Goodman, M. and Hansen, T. (2009) Marketing Management. Pearson Education Limited, Harlow.

[5]. Simamora, Henry. 2006. Manajemen Sumberdaya Manusia. Yogyakarta: Sekolah Tinggi Ilmu Ekonomi YKPN. 